\title{
Soluble Fiber Content and Acceptance in The Combination of Avocado and Apple Juice
}

\author{
${ }^{1}$ Luthfia Atikasari, ${ }^{2}$ Mohammad Jaelani, ${ }^{3}$ Yuwono Setiadi, ${ }^{4}$ Yuniarti, and ${ }^{5}$ Ria Ambarwati \\ ${ }^{1}$ Politeknik Kesehatan Kementrian Kesehatan Semarang, Indonesia, luthfiaatikasari10@gmail.com \\ ${ }^{2}$ Politeknik Kesehatan Kementrian Kesehatan Semarang, Indonesia, 10jaelani@gmail.com \\ ${ }^{3}$ Politeknik Kesehatan Kementrian Semarang, Indonesia, yuwonopoltekkes@yahoo.com \\ ${ }^{4}$ Politeknik Kesehatan Kementrian Semarang, Indonesia, yuni4rti1976@yahoo.com \\ ${ }^{5}$ Politeknik Kesehatan Kementrian Semarang, Indonesia, ria_mgiz09@yahoo.com \\ Coresponding author: Luthfia Atikasari, e-mail: luthfiaatikasari10@ gmail.com
}

\begin{abstract}
Avocados and apples are one of the foods high in soluble fiber that can be processed into functional drinks as an alternative food in overcoming hypercholesterolemia. Knowing the soluble fiber content and acceptability in the combination of avocado and apple juice. This study used an experimental method with a randomized design, consisting of 3 formulas, namely 50:50, 60:40, and 70:30 with 4 treatments. Water soluble fiber content by using enzymatic-test. Acceptance test on 30 women of childbearing age. Data analysis used one-way ANOVA test. The average soluble fiber content in the juice combination formula were 50:50 (8,19 g), 60:40 (9,81 g) and 70:30 (11,01 g). The acceptability test for the 50:50 and 60:40 formulas was rated somewhat like to like with an average rating on each parameter, which was 2,77 to 3,73 . The combination of avocado and apple juice contributes 25,61 $37,98 \%$ of fiber to the WUS RDA. The most preferred formula in the acceptability test assessment was 50:50 with an average fiber content of 8,19 $\mathrm{g}$ which was able to meet $28,26-27,32 \%$ of the daily fiber requirement.
\end{abstract}

\section{ARTICLE INFORMATION}

\author{
Submitted: $30 / 09 / 2021$ \\ Revised: 09/11/2021 \\ Accepted: 20/11/2021 \\ Publish Online: 22/11/2021
}

Keywords:
Acceptability
Apple
Avocado
Combination juice
Soluble fiber

Keywords:

Acceptability

Avocado

Soluble fiber

How to cite this article: Atikasari, L., Jaelani, M., Setiadi, Y., Yuniarti, Ambarwati, R., (2021). Soluble Fiber Content and Acceptance in The Combination of Avocado and Apple Juice. Journal of Nutrition Science, 2 (2), 23-31

\section{Introduction}

Hypercholesterolemia is a condition where high cholesterol levels in the blood exceed $200 \mathrm{mg} / \mathrm{dl}$ (Purhadi et al., 2019). The prevalence of high cholesterol according to gender, in men is $48 \%$ while women are higher at $54.3 \%$. In Central Java, the prevalence of high cholesterol reached $48.1 \%$. The 2018 Basic Health Research stated that based on gender, the proportion of the Indonesian population aged over 15 years who had cholesterol levels above normal, namely women, was $24 \%$ higher than men, which was $18.3 \%$ (Indonesian Ministry of Health Research and Development Agency, 2018).

Efforts that can be made in overcoming hypercholesterolemia are pharmacological therapy and non-pharmacological therapy. Pharmacological therapy is the use of chemical drugs which can cause side effects. This makes non-pharmacological treatment is also needed to reduce drug doses by utilizing dietary fiber from fruits such as avocados and apples.

Avocado (Persea americana) is a fruit that is high in monounsaturated fatty acids (MUFA), soluble fiber that plays a role in lowering LDL cholesterol and niacin (vitamin B3) which can help raise $\mathrm{HDL}$ cholesterol. Fat content reaches $71-81 \%$ of total calories or about 20 times that of the average other fruit and 7 grams of fiber per 100 grams of which $25 \%$ is soluble fiber and $75 \%$ insoluble fiber. (Budiawan, Mayulu and Rattu, 2019, Nurman and Afifah, 2019 and Muzakar and Audina, 2018). While apples (Malus domestica) are fruits that contain pectin which binds LDL cholesterol levels in the body and increases HDL levels (Nurman and Afifah, 2019). 
Based on the description above, the researchers are interested in conducting research on "Soluble Fiber Levels and Acceptance in the Combination of Avocado and Apple Juice" with the aim of knowing the soluble fiber content and acceptability of the combination of avocado and apple juice products.

\section{Methods}

This study used an experimental method with a completely randomized design, consisting of 3 formulas with 4 repetitions. The influence variable used is the combination formulation of avocado and apple juice, namely $\mathrm{K} 1$ = avocado: apple (50:50), K2 = avocado: apple (60:40), and K3 = avocado: apple (70:30), while the affected variables are soluble fiber content and acceptability.

This research was conducted at the researcher's house in Pedurungan Kidul Semarang. The ingredients used to make the juice combination were obtained from avocado farmers in the Bandungan area, Semarang and the apples were purchased from the ADA Majapahit supermarket, Semarang. The combination formulation of avocado and apple juice can be seen in table 1 .

Table 1. Combination Formulation of Avocado and Apple Juice

\begin{tabular}{|c|c|c|c|}
\hline \multirow{2}{*}{ Ingredients } & \multicolumn{3}{|c|}{$\begin{array}{c}\text { Formulation of Avocado and Apple } \\
\text { Juice }\end{array}$} \\
\hline & $\begin{array}{c}\mathbf{K 1} \\
(\mathbf{5 0 : 5 0 )}\end{array}$ & $\begin{array}{c}\mathrm{K} 2 \\
(60: 40)\end{array}$ & $\begin{array}{c}\text { K3 } \\
(\mathbf{7 0 : 3 0 )}\end{array}$ \\
\hline Avocado & $125 \mathrm{~g}$ & $150 \mathrm{~g}$ & $175 \mathrm{~g}$ \\
\hline Appel & $125 \mathrm{~g}$ & $100 \mathrm{~g}$ & $75 \mathrm{~g}$ \\
\hline Water & $155 \mathrm{ml}$ & $155 \mathrm{ml}$ & $155 \mathrm{ml}$ \\
\hline
\end{tabular}

Soluble fiber content was obtained from laboratory tests using the enzymatic method at the Chem-Mix Laboratory Pratama Bantul, Yogyakarta. Acceptability data was obtained by hedonic organoleptic test conducted by 30 consumer panelists in the form of Women of Childbearing Age (WUS).

Data processing is done with Microsoft Excel and data processing applications, namely SPSS 21.0. Normality test using Shapiro Wilk. The results of the soluble fiber content test used a one-way ANOVA test and further tests were carried out for BNT (Least Significant Difference) or LSD (Less Significances Different), while the data from the acceptability test results used Kruskal Wallis.

\section{Making Process}

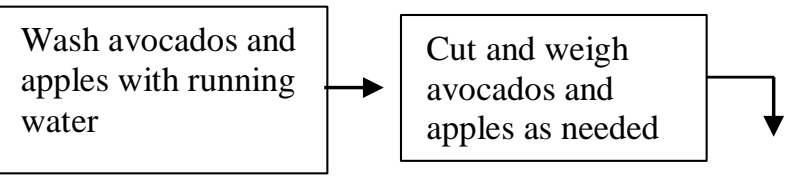

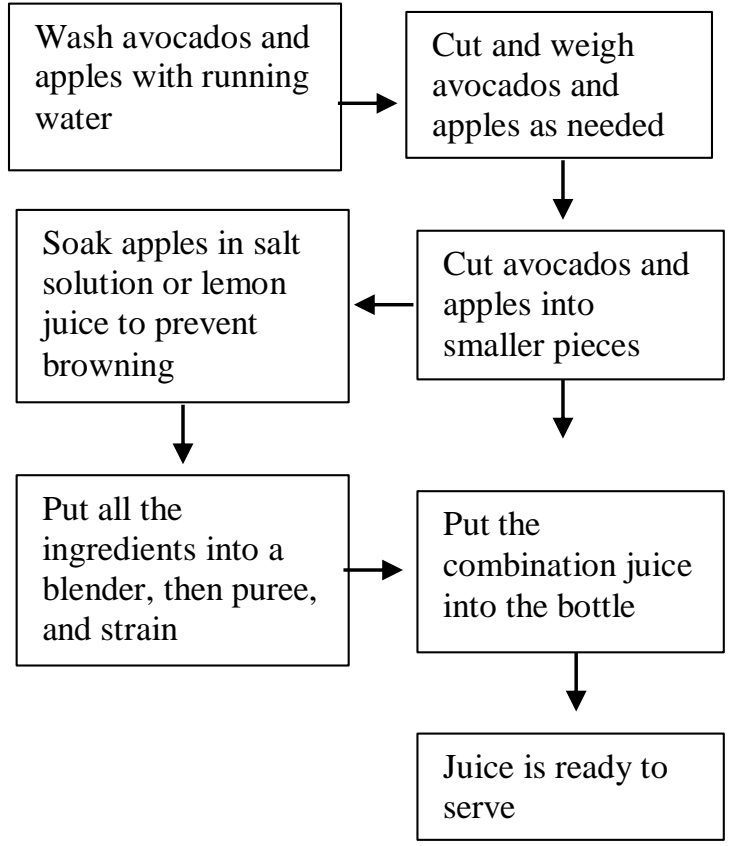

\section{Results and Discussion Acceptance}

\section{Organoleptic Test (Hedonic)}

Organoleptic test is a test method using human senses as the main tool in measuring the acceptability of a product (Iswendi et al., 2019). While the hedonic test is one type of acceptance test of a product (Novita et al., 2017). In this study, the hedonic test was carried out to determine the level of consumer preference and acceptance of the combination of avocado and apple juice based on the parameters of color, taste, aroma, and texture. This hedonic test was carried out by consumer panelists, namely women of childbearing age in the Pedurungan area of Semarang City as many as 30 people. The hedonic test was carried out by presenting 3 formulas for the combination of avocado and apple juice with different codes. The assessment of this test is carried out by giving a score or value for each parameter of color, taste, aroma, and texture in each formula of the combination of avocado and apple juice with assessment criteria, namely 1 (dislike very much), 2 (dislike), 3 (somewhat like), 4 (like), and 5 (like very much) (Hariati et al., 2018). The higher the value given, the panelists will like the formula presented and see the differences between products at the product development stage (Afriani et al., 2019). 
Table 2. The average organoleptic test assessment on the color, taste, scent, and texture of the combination of avocado and apple juice

\begin{tabular}{llll}
\hline Parameter & Treatment & Mean \pm SD & P value \\
\hline Colour & K1 & $3,40 \pm 0,855$ & 0,085 \\
& K2 & $3,73 \pm 0,640$ & \\
\multirow{5}{*}{ Taste } & K3 & $3,90 \pm 0,759$ & \\
& K1 & $3,43 \pm 0,858$ & 0,000 \\
& K2 & $2,77 \pm 0,626$ & \\
Scent & K3 & $2,30 \pm 0,702$ & \\
& K1 & $3,23 \pm 0,817$ & 0,419 \\
& K2 & $3,07 \pm 0,691$ & \\
Texture & K3 & $3,07 \pm 0,640$ & \\
& K2 & $3,30 \pm 0,750$ & 0,414 \\
& K3 & $3,23 \pm 0,935$ & \\
\hline Information & & $3,03 \pm 0,890$ &
\end{tabular}

Information :

$\mathrm{K} 1$ = combination of avocado and apple juice with a ratio of 50:50

$\mathrm{K} 2$ = combination of avocado and apple juice with a ratio of $60: 40$

$\mathrm{K} 3$ = combination of avocado and apple juice with a ratio of 70:30

In the color parameter, the results of the normality test using Shapiro-Wilk, obtained p-value $=0.000$ which means that the data is not normally distributed so that the statistical test is continued with the Krsukal-Wallis test and obtained $p$-value $=0.085$. It means that there is no effect of avocado and apple composition on the color of the three combination formulas of avocado and apple juice. In the taste parameter, the results of the normality test using Shapiro-Wilk, obtained pvalue $=0.000$ which means that the data is not normally distributed so that the statistical test is continued with the Krsukal-Wallis test and obtained pvalue $=0.000$. It means that there is an effect of the composition of avocado and apple on the taste of the three combination formulas of avocado and apple juice. In the aroma parameter, the normality test results using Shapiro-Wilk obtained p-value $=0.000$ which means that the data is not normally distributed so that the statistical test is continued with the KrsukalWallis test and obtained $p$-value $=0.419$. It means that there is no effect of avocado and apple composition on the aroma of the three combination formulas of avocado and apple juice. Then on the texture parameters of the results of the normality test using Shapiro-Wilk, p-value $=0.000$ was obtained, which means that the data was not normally distributed so that the statistical test was continued with Krsukal Wallis test and obtained $p$-value $=0.414$. It means that there is no effect of avocado and apple composition on the texture of the three combination formulas of avocado and apple juice.

Color is the first impression that is seen and appears and assessed by panelists in serving food (Lamusu, 2018). Color is one of the factors that can affect the level of liking and acceptance of a product. Color as the main attraction of a product before consumers judge the other qualities of the product. One of the ingredients in the formula for the combination of avocado and apple juice that can affect the color of the juice combination is the presence of apples which can cause browning, so the color of the juice can turn brown. In this study, the color of the combination of avocado and apple juice gets brown when the composition of apples is used more and more. According to Purwanto and Effendi, apples will experience a decrease in quality when they have gone through the cutting process because the apples will change color to browning due to the oxidation process. This process is triggered by an oxidation reaction catalyzed by the phenol oxidase enzyme (Purwanto $\&$ Effendi, 2016). The browning process on apples not only reduces the appearance quality but also reduces the taste of the apples themselves. In addition, it can cause a decrease in the appearance, organoleptic properties, and market value of the apples (Arsa, 2016). The browning process can be prevented by adjusting the $\mathrm{pH}$ to low because the polyphenol oxidase enzyme will decrease along with the low $\mathrm{pH}$ (Sariningsih \& Srimiati, 2018).

Table 3. The difference in the mean color of the avocado and apple juice combination

\begin{tabular}{cccc}
\hline \multicolumn{2}{c}{ Treatment } & Mean Difference & P value \\
\hline K1 & K2 & 0,333 & 0,930 \\
K2 & K3 & 0,167 & 0,362 \\
K3 & K1 & 0,500 & 0,200 \\
\hline
\end{tabular}

Based on the table above, there is no significant difference between the color parameters of the $\mathrm{K} 1, \mathrm{~K} 2$, and $\mathrm{K} 3$ formulas because the $\mathrm{p}$-value $>0.05$, which means there is no significant difference.

Taste is one way to choose food based on the difference in the taste of the food. Taste is influenced by 3 factors, namely smell, taste, and oral stimulation (hot or cold). The first factor is detected through the sense of smell and the second and third factors are detected by sensory cells in the sense of taste (Manurung \& Suriono, 2020). 
Table 4. The difference in the mean taste of the combination of avocado and apple juice

\begin{tabular}{cccc}
\hline \multicolumn{2}{c}{ Treatment } & Mean Difference & P value \\
\hline K1 & K2 & 0,667 & 0,010 \\
K2 & K3 & 0,467 & 0,009 \\
K3 & K1 & 1,133 & 0,000 \\
\hline
\end{tabular}

Based on the table above, it can be concluded that there are significant differences between the taste parameters of the $\mathrm{K} 1, \mathrm{~K} 2$, and $\mathrm{K} 3$ formulas. In the $\mathrm{K} 1$ and $\mathrm{K} 2$ formulas with a $95 \%$ confidence level, $\mathrm{p}$-value $=0.010(\mathrm{p}<0.05)$ was obtained, which means that there was a significant difference between the taste parameters of the $\mathrm{K} 1$ and $\mathrm{K} 2$ formulas. Meanwhile, in the $\mathrm{K} 2$ and $\mathrm{K} 3$ formulas with a $95 \%$ confidence level, p-value $=0.009(\mathrm{p}<0.05)$ was obtained, which means that there was a significant difference between the taste parameters for the $\mathrm{K} 2$ and $\mathrm{K} 3$ formulas, as well as in the $\mathrm{K} 3$ and $\mathrm{K} 1$ formulas with a $95 \%$ confidence degree. we get $p$-value $=0.000(p<0.05)$ which means that there is a significant difference between the taste parameters of the $\mathrm{K} 3$ and $\mathrm{K} 1$ formulas.

Scent is a reaction from food that will affect consumers before enjoying food, consumers can smell (smell of smell) the food before enjoying it (Adinugraha \& $\mathrm{H}, 2015$ ). Consumers are able to judge whether a food is delicious or not, it can be seen from the scent produced and from the ingredients contained in the food (Violita \& Purba, 2021). The more avocado composition in the juice combination, the lower the level of preference for scent. This can be caused by the quality of the avocado which has begun to decline as if it is too ripe so that an sour-like scent appears (Ashari, 2020).

Table 5. The difference in the mean scent of the combination of avocado and apple juice

\begin{tabular}{cccc}
\hline \multicolumn{2}{c}{ Treatment } & Mean Difference & P value \\
\hline K1 & K2 & 0,167 & 0,010 \\
K2 & K3 & 0,000 & 1,000 \\
K3 & K1 & 0,000 & 1,000 \\
\hline
\end{tabular}

Based on the table above, it can be concluded that there is no significant difference between the scent parameters on the $\mathrm{K} 1, \mathrm{~K} 2$, and $\mathrm{K} 3$ formulas because the $p$-value $>0.05$, which means there is no significant difference.

Texture is psychophysical which means that it can be measured physically and psychologically by the senses. Meanwhile, from the point of view of the senses, texture is related to feeling. So that food texture can only be assessed after the food is consumed (Noor, 2017). The more avocado composition in the juice combination, the lower the level of preference for texture. This is because the composition of many avocados in the combination formulation of avocado and apple juice will make the juice thicker.

Table 6. The difference in the mean texture of the combination of avocado and apple juice

\begin{tabular}{cccc}
\multicolumn{2}{l}{ Treatment } & Mean Difference & P value \\
\hline K1 & K2 & 0,067 & 0,762 \\
K2 & K3 & 0,200 & 0,400 \\
K3 & K1 & 0,267 & 0,215 \\
\hline
\end{tabular}

Based on the table above, it can be concluded that there is no significant difference between the texture parameters of the $\mathrm{K} 1, \mathrm{~K} 2$, and $\mathrm{K} 3$ formulas because the $\mathrm{p}$-value $>0.05$, which means there is no significant difference.

\section{Big Portion}

Big portion aims to see whether the combination formula of avocado and apple juice can be accepted by consumers or not. This acceptance was carried out by consumer panelists, namely women of childbearing age in the Pedurungan area of Semarang City as many as 30 people. Acceptance is done by presenting 3 formulas for the combination of avocado and apple juice with different codes and given on different days. This acceptance assessment is seen from how many portions are able to be spent by the panelists. If you can spend up to $50 \%$ of the portion served, the formula can be accepted by consumers.

Table 7. Distribution of large portion ratings on the combination of avocado and apple juice

\begin{tabular}{lcccc}
\hline \multirow{2}{*}{ Big Portion } & \multicolumn{3}{c}{ Formula } & \multirow{2}{*}{ Total } \\
\cline { 2 - 4 } & K1 & K2 & K3 & \\
\cline { 2 - 4 } & $\mathbf{N}$ & $\mathbf{N}$ & $\mathbf{N}$ & $\mathbf{N}$ \\
\hline $\mathbf{0 \%}$ & 1 & 1 & 3 & 5 \\
$\mathbf{2 5 \%}$ & 2 & 7 & 17 & 26 \\
$\mathbf{5 0 \%}$ & 12 & 16 & 9 & 37 \\
$\mathbf{7 5 \%}$ & 7 & 5 & 0 & 12 \\
$\mathbf{9 5 \%}$ & 5 & 1 & 1 & 7 \\
$\mathbf{1 0 0 \%}$ & 3 & 0 & 0 & 3 \\
Sum & 30 & 30 & 30 & 90 \\
\hline
\end{tabular}

From the table above, it can be stated that in the K1 formula there are 1 person who has not been able to finish the juice, 2 people are able to drink up to $25 \%$ of the portion served, 12 people are able to spend up to $50 \%$ of the portion served, 7 people are able to spend up to $75 \%$ of the portion served. servings, 5 people are able to consume up to $95 \%$ of the servings served, and 3 people are able to finish all the juices served. In the $\mathrm{K} 2$ formula there are 1 person who has not been able to finish the served juice, 7 people are able to spend up to $25 \%$ of the serving served, 16 
people are able to spend up to $50 \%$ of the served portion, 5 people are able to spend up to $75 \%$, and 1 person is able to spend up to $95 \%$ of servings. While in the $\mathrm{K} 3$ formula there are 3 people who are unable to finish the served juice, 17 people are able to spend up to $25 \%$ of the serving served, 9 people are able to spend up to $50 \%$ of the served portion, and 1 person is able to spend up to $95 \%$ of the served portion. .

Based on the table, it can be concluded that in the K1 formula there were 27 people who were able to spend up to $50 \%$ of the juice so that it can be said that the K1 formula from the combination of avocado juice was acceptable to consumers. While in the $\mathrm{K} 2$ formula there are 22 people who are able to drink a combination of $50 \%$ juice so it can be said that the K2 formula from a combination of avocado juice is acceptable to consumers, and in the $\mathrm{K} 3$ formula there are only 10 people who are able to drink a combination of $50 \%$ juice so it can be said that the K3 formula from the combination of avocado juice has not been accepted by consumers because there are still few panelists who can drink juice up to $50 \%$.

\section{Water Soluble Fiber Content}

The content of soluble fiber is fiber that is able to bind fat in the small intestine, therefore this type of fiber can help lower cholesterol levels in the blood (Fairudz $\&$ Nisa, 2015). In this study, the water soluble fiber content in the combination of avocado and apple juice was obtained using the Enzymatic method carried out at the Chem-Mix Laboratory, Bantul, Yogyakarta. The soluble fiber content test was repeated 4 times, where each treatment was coded as K1 (50:50), K2 (60:40) and K3 (70:30). The test was treated 4 times to get accurate and relevant results. The results of the analysis of soluble fiber content can be seen in table 8 .

Table 8. Average results of laboratory tests for soluble fiber content of a combination of avocado and apple juice

\begin{tabular}{cc}
\hline $\begin{array}{c}\text { Avocado and Apple Juice } \\
\text { Combination Treatment }\end{array}$ & $\begin{array}{c}\text { Soluble Fiber Content } \\
\text { (g) }\end{array}$ \\
\hline K1 (50:50) & 8,1961 \\
K2 (60:40) & 9,8103 \\
K3 (70:30) & 11,0144 \\
\hline
\end{tabular}

Table 8 shows that the soluble fiber content in the combination formula of avocado and apple juice $\mathrm{K} 1$ $(50: 50)$ is $8.161 \mathrm{~g} / 100 \mathrm{~g}, \mathrm{~K} 2(60: 40)$ is $9.8103 \mathrm{~g} / 100$ $\mathrm{g}$, and $\mathrm{K} 3(70: 40 \mathrm{~g}) .30)$ of $11.0144 \mathrm{~g} / 100 \mathrm{~g}$.

Based on the results of the study showed that the more avocado composition in the combination of avocado and apple juice, the higher the soluble fiber content in the combination of avocado and apple juice, because the avocado itself is rich in fiber, every 2 tablespoons of avocado contains about 2 grams of fiber, so the whole flesh of the fruit contains about 10 grams of fiber (Wijayanti et al., 2014). This is in line with research by Muzakar and Audina which states that every 100 grams of avocado contains 7 grams of fiber, of which $25 \%$ is soluble fiber and $75 \%$ is insoluble fiber (Muzakar \& Audina, 2018). While apples only have 2.6 grams of fiber for every 100 grams of apples (TKPI, 2017).

Table 9. Average soluble fiber content of the combination of avocado and apple juice

\begin{tabular}{ccc}
\hline Formula & Mean \pm SD & P value \\
\hline K1 & $8,196 \pm 0,812$ & 0,000 \\
K2 & $9,810 \pm 0,082$ & 0,000 \\
K3 & $11,014 \pm 0,301$ & 0,000 \\
\hline
\end{tabular}

The results of the normality test using Shapiro-Wilk obtained p-value $=0.546$ which means the data is normally distributed so that the statistical test is continued with the one-way ANOVA test and obtained $\mathrm{p}$-value $=0.000$ which means that there is a significant effect between the combination formulation of avocado and apple juice on fiber. late. Then continued with Duncan's test and obtained pvalue $=0.000(p<0.05)$. This also indicates that all the combination treatments of avocado and apple juice affect the soluble fiber content.

Table 10. The difference in the average soluble fiber content of the combination of avocado and apple juice

\begin{tabular}{cccc}
\hline Treatment & & Mean Difference & P value \\
\hline K1 & K2 & 1,614 & 0,007 \\
K2 & K3 & 1,204 & 0,040 \\
K3 & K1 & 2,818 & 0,038 \\
\hline
\end{tabular}

Based on 18 it can be concluded that there is a significant difference between the soluble fiber content and the combination formula of avocado and apple juice. In the $\mathrm{K} 1$ and $\mathrm{K} 2$ formulations with a $95 \%$ confidence level, the $\mathrm{p}$-value $=0.007(\mathrm{p}<0.05)$ which means there is a significant difference between the soluble fiber content in the $\mathrm{K} 1$ and $\mathrm{K} 2$ formulas. Meanwhile, in the K2 and K3 formulas with a 95\% confidence level, $\mathrm{p}$-value $=0.040(\mathrm{p}<0.05)$ was obtained, which means that there was a significant difference between the soluble fiber content in $\mathrm{K} 2$ and $\mathrm{K} 3$ formulas, as well as in $\mathrm{K} 3$ and $\mathrm{K} 1$ formulas with a 95 confidence degree. $\%$ obtained p-value $=0.038$ $(\mathrm{p}<0.05)$ which means that there is a significant 
difference between the levels of soluble fiber in the $\mathrm{K} 3$ and $\mathrm{K} 1$ formulas.

The formulation composition of the combination of avocado and apple juice was made different, which caused the soluble fiber test results to be different. The $\mathrm{K} 3$ formula contains more avocado composition than the $\mathrm{K} 1$ and $\mathrm{K} 2$ formulas. The composition in formula $\mathrm{K} 1$ has a ratio of 50:50 between avocado and apple while formula K2 has a ratio of 60:40 between avocado and apple.

Fiber Contribution of Avocado and Apple Juice Combination Based on RDA for Women of Childbearing Age (WUS)

The contribution of fiber in women of childbearing age can be seen in table 11 below.

Table 11. Fiber contribution of the combination of avocado and apple juice based on the RDA for women of childbearing age

\begin{tabular}{|c|c|c|c|c|}
\hline \multirow[b]{2}{*}{ Formula } & \multirow[b]{2}{*}{$\begin{array}{l}\text { Mean Fiber } \\
\text { Content (g) }\end{array}$} & \multicolumn{3}{|c|}{ Contribution (\%) } \\
\hline & & $\begin{array}{c}\text { 13-18 } \\
\text { years } \\
\text { old }\end{array}$ & $\begin{array}{c}19-29 \\
\text { years } \\
\text { old }\end{array}$ & $\begin{array}{c}30-49 \\
\text { years } \\
\text { old }\end{array}$ \\
\hline K1 & 8,1961 & 28,26 & 25,61 & 27,32 \\
\hline $\mathrm{K} 2$ & 9,8103 & 33,82 & 30,65 & 32,70 \\
\hline K3 & 11,0144 & 37,98 & 34,42 & 36,71 \\
\hline
\end{tabular}

Every 1 serving of $250 \mathrm{ml}$ avocado and apple combination juice (1 bottle) of formula K1 can contribute fiber by $28.26 \%$ for ages $13-18$ years, $25.61 \%$ for ages $19-29$ years, and $27.32 \%$ for ages 30 49 years. In the K2 formula, it can contribute $33.82 \%$ fiber for 13-18 years old, $30.65 \%$ for $19-29$ years old, and $32.70 \%$ for $30-49$ years old. While the K 3 formula can contribute fiber by $37.98 \%$ for ages $13-18$ years, $34.42 \%$ for ages $19-29$ years, and $36.71 \%$ for ages 30 49 years. The results showed that the combination of avocado and apple juice with the formula K1 (50:50), K2 (60:40), and K3 (70:30) had met the adequacy of fiber at least $20 \%$ of the RDA for women of childbearing age. Food is said to be high in fiber content if it is able to meet the adequacy of at least $20 \%$ of the recommended RDA for each serving (RDA, 2019).

Soluble fiber is able to bind fat so that it can reduce cholesterol levels by up to $5 \%$. Not only that, fiber is also able to excrete bile acids which causes the synthesis of bile acids to increase. This increase in bile acids can cause the liver to take up more cholesterol, resulting in a decrease in cholesterol (Utama \& Yunita, 2019). Therefore, dietary fiber can reduce high cholesterol levels. Thus, the fiber content in the combination of avocado and apple juice can help prevent or reduce high cholesterol in the blood. In addition, it can prevent the risk of atherosclerosis and cardiovascular events due to high cholesterol (Santoso, 2011).

\section{Conclusion}

There is a significant effect between the composition of avocado and apple on the soluble fiber content of the combination of avocado and apple juice. There was no significant effect between the composition of avocado and apple on color parameters in the organoleptic test of the combination of avocado and apple juice. There is a significant effect between the composition of avocado and apple on taste parameters in the organoleptic test of the combination of avocado and apple juice. There was no significant effect between the composition of avocado and apple on aroma parameters in the organoleptic test of the combination of avocado and apple juice. There was no significant effect between the composition of avocado and apple on texture parameters in the organoleptic test of the combination of avocado and apple juice. The combination formula of avocado and apple juice contributed the highest addition of soluble fiber as much as $37.98 \%$ and the lowest as much as $25.61 \%$. And the combination formula of avocado and apple juice that can be accepted by consumers is the K1 formula with a ratio of 50:50 and the $\mathrm{K} 2$ formula with a ratio of $60: 40$.

\section{Acknowledgement}

The author would like to thank the Undergraduate Study Program in Applied Nutrition and Dietetics, Department of Nutrition, Poltekkes, Ministry of Health, Semarang, which has facilitated the research and supervisors and examiners who always provide direction and guidance patiently. In addition, the authors also thank the research respondents for their participation and contribution in this study.

\section{Author Contribution and Competing Interest}

The author greatly contributed to the implementation and preparation of research, from the preparation of tools and materials to the testing process for respondents and laboratories

\section{References}

Adinugraha, A. T., \& H, S. M. (2015). Analisa Pengaruh Kualitas Makanan Dan Persepsi Harga Terhadap Kepuasan Konsumen D'cost Surabaya. Jurnal Hospitality Dan Manajemen 
Jasa, 3 , 643-655. http://publication.petra.ac.id/index.php/manaje men-perhotelan/article/view/3571/3239

Afriani, Y., Wahyuningsih, S., Kadaryati, S., \& Yuliana, E. P. (2019). Uji Organoleptik Formula Minuman Olahraga Berbasis Jamur Tiram Putih (Pleurotus ostreatus). Prosiding Seminar Nasional, 1. http://prosiding.respati.ac.id/index.php/PSN/arti cle/view/238/232

AKG. (2019). Angka Kecukupan Gizi Yang Dianjurkan Untuk Masyarakat Indonesia.

Apriliani, R., Tamrin, \& Hermanto. (2019). Pengaruh Penambahan Kayu Manis (Cinnamomum verum) Terhadap Karakteristik Organoleptik Dan Antioksidan Minuman Sari Buah Alpukat (Perseaamericana mill). Jurnal Sains Dan Teknologi Pangan, 4, 2621-2634. http://ojs.uho.ac.id/index.php/jstp/article/viewFi le/10900/7734

Arsa, M. (2016). Proses Pencoklatan (Browning Process) Pada Bahan Pangan [Universitas Udayana Denpasar Bali]. https://repositori.unud.ac.id/protected/storage/u pload/repositori/19253af34abbcd36474ef96547 318f9d.pdf

Ashari, A. (2020). Suka Simpan Alpukat di Rumah? Perhatikan Tanda Alpukat Sudah Tidak Baik Dikonsumsi. Bobo. https://bobo.grid.id/read/082075117

Badan Penelitian dan Pengembangan Kesehatan Kemenkes RI. (2018). HASIL UTAMA RISKESDAS 2018. https://kesmas.kemkes.go.id/assets/upload/dir_5 19d41d8cd98f00/files/Hasil-riskesdas2018_1274.pdf

Badan Standarisasi Nasional. (2014). Minuman sari buah SNI 3719:2014. www.bsn.go.id

Bisu, Y. N. (2018). Aktivitas Antioksidan Dan Sifat Kimia Jus Alpukat Dengan Variasi Konsentrasi Penambahan Gel Lidah Buaya (Aloe vera var. Chinensis) [Universitar Mercu Buana Yogyakarta]. http://eprints.mercubuanayogya.ac.id/id/eprint/5164

Budiawan, H., Mayulu, N., \& Rattu, A. J. M. (2019). Pengaruh Pemberian Alpukat Dengan Atau Tanpa Senam Aerobik Terhadap Kadar
Kolesterol Higd Density Lipoprotein (HDL) Pada Wanita Dewasa Muda Di Universitas Katolik De La Salle Manado. Graha Medika Nursing Journal, 2, 82-90.

D, G., \& Pamplona-Roger. (2016). Makanan Menyehatkan (R. M. Hutasoit (ed.); Pola Hidup). Editorial Safeliz dan Indonesia Publishing House. www.safeliz.com

Dai, F.-J., \& Chau, C.-F. (2017). Classification and regulatory perspectives of dietary fiber. Journal of Food and Drug Analysis, 37-42. https://doi.org/http://dx.doi.org/10.1016/j.jfda.2 016.09 .006

Dr. Mehmet. (2017). Food Can Fix It (M. Ariyani (ed.); 1st ed.). Bhuana Ilmu Populer.

Fairudz, A., \& Nisa, K. (2015). Pengaruh Serat Pangan terhadap Kadar Kolesterol Penderita Overweight. MAJORITY, 4, 121-126. http://juke.kedokteran.unila.ac.id/index.php/maj ority/article/view/1485/1324

Hariati, N., Ansharullah, \& Asyik, N. (2018). Pengaruh Penambahan Tepung Beras Merah (Oriza nivara l.) Terhadap Uji Organoleptik Dan Proksimat Bolu Kukus. Jurnal Sains Dan Teknologi Pangan, 3. http://ojs.uho.ac.id/index.php/jstp/article/viewFi le/3973/3049

Ifora, Dharma, S., \& Darma, D. M. (2016). Pengaruh Pemberian Kombinasi Jahe Merah, Bawang Putih, Apel, Lemon Dan Madu Terhadap Kadar Kolesterol Total Dan Histopatologis Pembuluh Darah Aorta Jantung Tikus Putih Jantan. Jurnal Farmasi Higea, 8, 163-174. diken2094@gmail.com

Indrawati, V. P. (2018). Efektivitas Pemberian Jus Tomat Dan Jus Apel Terhadap Perubahan Kadar Kolesterol Darah Pada Orang Dewasa Dengan Hiperkolesterolemia Di Posbindu Wilayah Puskesmas Bendo [STIKES Bhakti Husada Mulia]. In Doctoral Disertation, STIKES Bhakti Husada Mulia. http://repository.stikesbhm.ac.id/id/eprint/134

Iswendi, Yusmaita, E., \& Pangestuti, A. D. (2019). Uji Organoleptik Sari Jagung Di Laboratorium Kimia FMIPA UNP. Jurnal Ilmiah Pengabdian Keapada Masyarakat, 19. https://doi.org/http://dx.doi.org/10.2403/sb.0100 
Izzati, W., \& Salsabila, R. M. V. (2018). Pengaruh Jus Apel Hijau Terhadap Penurunan Kolesterol Pada Penderita Hipertensi Di Nagari Kapalo Koto Wilayah Kerja Puskesmas Tigo Baleh Bukittinggi Tahun 2017. Afiyah, 5, 66-70. http://www.ejournal.stikesyarsi.ac.id/index.php/ JAV1N1/article/download/159/242\#: :text=Ap el memang makanan bebas kolesterol,darah (Anies\%2C 2015).

Jayanti, W. T. (2017). Substitusi Tepung Terigu Dengan Tepung Biji Alpukat Terhadap Sifat Fisik Cookies. Universitas Diponegoro Semarang.

Kemenkes. (2016). Profil Penyakit Tidak Menular Tahun 2016 (2016th ed.).

Kemenkes RI. (2018). Pengawasan Mutu Pangan (1st ed.). Badan Pengembangan dan Pemberdayaan Sumber Daya Manusia Kesehatan. http://bppsdmk.kemkes.go.id/pusdiksdmk/wpcontent/uploads/2018/05/Pengawasan-MutuPangan_SC.pdf

Kusumastuty, I., Harti, L. B., \& Misrina, S. A. (2016). Perbedaan Kandungan Serat Pangan Pada Makanan Siap Saji Khas Indonesia Yang Dianalisis Dengan Menggunakan Nutrisurvey Dan Enzimatik Gravimetri. Majalah Kesehatan FKUB, 3, 196-203. https://majalahfk.ub.ac.id/index.php/mkfkub/art icle/view/111/100

Kuswandi, Octriana, L., Kuswara, B., \& Nofiarli. (2017). Eksplorasi, Karakterisasi, dan Evaluasi Idiotipe Alpukat di Kabupaten Solok. Jurnal Agroteknologi Universitas Andalas, 1, 26-29. http://www.jagur.faperta.unand.ac.id/

Lamusu, D. (2018). Uji Organoleptik Jalangkote Ubi Jalar Ungu ( Ipomoea batatas L) Sebagai Upaya Diversifikasi Pangan. Jurnal Pengolahan Pangan, 3, 9-15. https://pengolahanpangan.jurnalpertanianunisap alu.com/index.php/pangan/article/download/7/8

Manurung, H. P., \& Suriono, H. (2020). Pengaruh Kualitas Pelayanan, Inovasi Dan Cita Rasa Makanan Terhadap Kepuasan Pengunjung Wisata Danau Buatan Kelapa Gading Kisaran. Prosiding Seminar Nasional Multidisiplin Ilmu Universitas Asahan Ke-4 Tahun 2020, 487-500. http://www.jurnal.una.ac.id/index.php/semnasm udi/article/view/1563/1279\#

Muzakar, \& Audina, B. (2018). Pengaruh Pemberian Jus Alpukat (Persea gratissima) Terhadap Perubahan Konstipasi Pada Lansiadi Panti Tresna Werdha Teratai Kota Palembang Tahun 2016. PUBLIKASI PENELITIAN TERAPAN DAN KEBIJAKAN, 1, 30-35. http://ejournal.sumselprov.go.id

Noor, R. (2017). Faktor-Faktor Kepuasan Pasien Dengan Sisa Makanan Pada Pelayanan Gizi Di Ruang Rawat Inap Rumah Sakit Islam Arafah Rembang [Universitas Muhammadiyah Semarang]. http://repository.unimus.ac.id/id/eprint/527

Novalinda, D. A. (2017). Snack Bar Tepung Beras Hitam Dan Tepung Ampas Tahu Sebagai Alternatif Snack Tinggi Serat [Poltekkes Kemenkes Semarang]. http://repository.poltekkes-

smg.ac.id/index.php?p=show_detail\&id=14255 \&keywords=ampas+tahu

Nugraha, Setya, D., \& Muhlisin, A. (2018). Gambaran Karakteristik Responden, Riwayat Penyakit Yang Menyertai Dan Jenis Penyakit Reumatik Pada Lansia Di Wilayah Kerja Puskesmas Kecamatan Bungkal Kabupaten Ponorogo [Universitas Muhammadiyah Surakarta]. http://eprints.ums.ac.id/60204/

Nuraini, D. N. (2017). Pro-Kontra Aneka Minuman Bagi Kesehatan. Penerbit Gava Media.

Nurjanah, Jacoeb, A. M., Hidayat, T., \& Chrystiawan, R. (2018). Perubahan Komponen Serat Rumput Laut Caulerpa sp. (Dari Tual, Maluku) Akibat Proses Perebusan. Jurnal Ilmu Dan Teknologi Kelautan Tropis, 10, 35-48. http://journal.ipb.ac.id/index.php/jurnalikt/articl e/view/21545

Nurman, M., \& Afifah, A. (2019). Studi Perbandingan Jus Apel Dan Jus Alpukat Terhadap Penurunan Kadar Kolesterol Pada Orang Yang Mengalam Hiperkolesterolemia Di Wilayah Kerja Puskesmas Bangkinang Kota. Jurnal Ners, 3, 114-120.

http://journal.universitaspahlawan.ac.id/index.p $\mathrm{hp} /$ ners

Pramudito, Pramudk, Fuskhah, Eny, \& Sumarsono. (2018). Efektivitas Penambahan Hormon Auksin 
(Iba) Dan Sitokinin (Bap) Terhadap Sambung Pucuk Alpukat (Persea americana Mill.) [Universitas http://eprints.undip.ac.id/61454/ Diponegoro].

Purhadi, Purnanto, N. T., \& Sutrisno. (2019). Efektivitas Pemberian Jus Buah Alpukat Terhadap Penurunan Kadar Kolesterol Di Desa Ngabenrejo Kecamatan Grobogan Kabupaten Grobogan. 4, 39-42.

Purwanto, Y. A., \& Effendi, R. N. (2016). Penggunaan Asam Askorbat dan Lidah Buaya untuk Menghambat Pencoklatan pada Buah Potong Apel Malang. Jurnal Keteknikan Pertanian, 4, 203-210.

https://doi.org/10.19028/jtep.04.2.203-210

Rahman, S. (2016). Studi Pendahuluan Pengaruh Alpukat Terhadap Profil Lemak di Poli Penyakit Dalam Klinik Iman. Buletin Farmatera, 1, 1-9.

Rantika, N., \& Rusdiana, T. (2018). Artikel Tinjauan: Penggunaan Dan Pengembangan Dietary Fiber. Farmaka, 16. http://jurnal.unpad.ac.id/farmaka/article/downlo $\mathrm{ad} / 17790 / \mathrm{pdf}$

Risyad, A., Permadani, L. R., \& Siswarni, M. Z. (2016). Ekstraksi Minyak Dari Biji Alpukat (Persea americana Mill) Menggunakan Pelarut N-Heptana. Jurnal Teknik Kimia USU, 5, 34-39. resi.levi.permadani@gmail.com

Santoso, A. (2011). Serat Pangan (Dietary Fiber) Dan Manfaatnya Bagi Kesehatan. Magistra, 35-40. http://fmipa.umri.ac.id/wp-

content/uploads/2016/09/Pinki-A-Serat-danmanfaatnya-bg-kesehatan-74-129-1-SM.pdf

Sariningsih, E., \& Srimiati, M. (2018). Formulasi Jus Alpukat Dengan Air Kelapa Muda Yang Berpotensi Menurunkan Hipertensi. Nutri-Sains, 2.

https://pdfs.semanticscholar.org/fff4/ce390d03b 7f2c48c56580cebf719a8f3eec5.pdf

Sitompul, D. I. S. (2019). Pengaruh Jus Buah Apel Terhadap Ph Saliva Pada Siswa/i Kelas VII Smp Swasta Taman Siswa Kecamatan Sawit Seberang Kabupaten Langkat [Poltekkes Kemenkes Medan]. http://poltekkes.aplikasiakademik.com/xmlui/handle/123456789/725

Susanto, D. B. (2019). Jus Dahsyat Tumpas Penyakit, Sehat \& Awet Muda. Cemerlang Publishing. cemerlang_yk@yahoo.co.id

Susilowati, E. (2010). Kajian Aktivitas Antioksidan, Serat Pangan, Dan Kadar Amilosa Pada Nasi Yang Disubstitusi Dengan Ubi Jalar (Ipomoea batatas L.) Sebagai Bahan Makanan Pokok [Universitas Sebelsa Maret]. https://core.ac.uk/download/pdf/12352299.pdf

Sutopo, D. (2019). Functional Food (J. Suzana (ed.)). PT Elex Media Komputindo. elex@elexmedia.id

Tim Karya Tani Mandiri. (2019). Rahasia Sukses Bertanam Alpukat (1st ed.). Nuansa Aulia. http://www.nuansaaulia.com

Tim Sarasvati. (2019). Jus Super untuk Perempuan Aktif (I. Hardiman (ed.); 1st ed.). PT Gramedia Pustaka Utama.

TKPI. (2017). Tabel Komposisi Pangan Indonesia. Kementrian Kesehatan RI.

USDA. (2019). Food Data Central. fdc.nal.usda.gov.

Utama, L. J., \& Yunita, L. (2019). Formulasi, Uji Daya Terima dan Analisis Kandungan Gizi Es Krim Pangan Fungsional Tinggi Protein dan Serat Berbasis Beras Hitam, Kacang Merah dan Kelor. Prosiding Semnas Sanitasi, 78-90. juntra8686@gmail.com

Violita, Lady, \& Purba, R. (2021). Uji Organoleptik Dan Analisis Kandungan Gizi Cookies Subtitusi Tepung Biji Alpukat. Journal Nutrition and Culinary, 1 . https://jurnal.unimed.ac.id/2012/index.php/JNC/ article/view/26854/16565

Wahyuningtias, D. (2010). Uji Organoleptik Hasil Jadi Kue Menggunakan Bahan Non Instant Dan Instant. BINUS BUSINESS REVIEW, 1, 116125.

https://journal.binus.ac.id/index.php/BBR/articl e/download/1060/1307

Waruwu, P. S. (2020). Pengaruh Pemberian Alpukat Terhadap Kadar Kolesterol Total Darah Pada Mahaiswa/i Obesitas Di Fakultas Kedokteran Universitas HKBP Nommensen Medan Tahun 2019. Repository Universitas HKBP Nommensen. http://repository.uhn.ac.id/handle/123456789/40 12

Wati, W. A. A., Jaelani, M., \& Sulistyowati, E. (2019). 
Pengaruh Smoothies Kombinasi Aneka Buah Dan Sayur Terhadap Penurunan Kadar Kolesterol Total. Jurnal Riset Gizi, 7, 1-8.

Widia, F. (2017). Perbedaan Pengaruh Pemberian Jus Apel Hijau Dengan Jus Apel Merah Terhadap Kadar Kolesterol Total Penderita Hiperkolesterolemia Di Laboratorium Kesehatan Padang Tahun 2017. Politeknik Kesehatan Kemenkes Padang.

Widowati, E., Utami, R., Amanto, B. S., Mahadjoene, E., \& Putri, A. A. (2020). Pengaruh Kombinasi Enzim Pektinesterase dan Poligalakturonase terhadap Klarifikasi Sari Buah Apel Varietas Manalagi. AgriTECH, 4, 290-298. https://doi.org/http://doi.org/10.22146/agritech. 43165

Widyaningrum, H. (2019). Kitab Tanaman Obat Nusantara (A. Rahmat (ed.); 2nd ed.). Media Pressindo. www.media-pressindo.com

Wijayanti, Yulina, \& Elliya, R. (2014). Pengaruh Pemberian Jus Alpukat (Persea Americana Mill) Terhadap Penurunan Kolestrol Tikus Putih Jantan (Rattus novergicus) Galur Wistar Kota Bandar Lampung Tahun 2014. Jurnal Kesehatan Holistik, 8, 147-152.

Winarno, E. (2018). Efektifitas Jus Buah Naga Dan
Jus Buah Alpukat Terhadap Penurunan Gula Darah Pada Penderita Diabetes Melitus Di Puskesmas Krompol Kecamatan Bringin Kabupaten Ngawi [Stikes Bhakti Husada Mulia Madiun]. http://repository.stikesbhm.ac.id/id/eprint/160

Zaddana, C., Almasyhuri, \& Shalatin, R. A. (2020). Selai Lembaran Kombinasi Apel (Malus sylvestris (L.) Mill.) Dan Teh Hijau (Camellia sinensis L.) Sebagai Pangan Fungsional (Sheet jam based on apple and green tea as a functional food). Jurnal AcTion: Aceh Nutrition Journal, 5, 87-97.

http://dx.doi.org/10.30867/action.v5i1.267

Zai, K., Sidabalok, I., \& Asnurita. (2021). Karakteristik Mutu Flakes Dengan Substitusi Tepung Biji Alpukat (Persea Americana Mill) Terhadap Tepung Terigu. Jurnal Pionir LPPM Universitas Asahan, 7, 10-20. http://jurnal.una.ac.id/index.php/pionir/article/vi ew/1821/1497

Zukhri, S., Meinisa, T. I., \& Sulistyowati, A. D. (2018). Perbedaan Pengaruh Jus Jambu Biji Dengan Jus Apel Hijau Terhadap Penurunan Kadar Kolesterol Darah. Motorik, 13, 213. 